\title{
Studies on Preparation and Quality of Nutritious Noodles by Incorporation of Defatted Rice Bran and Soy Flour \\ Pakhare KN ${ }^{1}$, Dagadkhair AC $^{1 *}$, Udachan IS $^{2}$ and Andhale RA
}

${ }^{1}$ Department of Technology, Food Technology Division, Shivaji University, Kolhapur, India

${ }^{2}$ MIT College of Food Technology, Rajbaugh, Loni Kalbhor, Pune, India

${ }^{3}$ College of Food Technology, VNMKV, Parbhani, India

\begin{abstract}
The protein and fiber rich noodles were prepared by incorporation of defatted soy flour (DSF) and defatted rice bran (DRB). The quantity DSF and DRB was used at $10 \%$ and $6 \%$ respectively for incorporation. The chemical composition of incorporated noodles utters the information such as, moisture $8.43 \%$, total carbohydrate $68.30 \%$, crude protein $14.29 \%$, crude fat $4.98 \%$, crude fiber $4.02 \%$, ash $1.54 \%$ and calcium $498 \mathrm{mg} / 100 \mathrm{~g}$ which reveals it's a good source of nutrients. The cooking quality was also examined and conclusions are; cooking time $7.30 \mathrm{~min}$, cooking loss $1.25 \mathrm{~g}$ and water uptake $10.5 \mathrm{~g}$. The DSF and DRB greatly affect the chemical composition and cooking quality of noodles, as soy and rice bran are the rich sources of protein and fiber respectively. The shelf life study was conducted by undertaking microbial study of noodles packed in different packaging material's viz. HDPE and LDPE. Though TPC of HDPE packed noodles was between $0.1 \times 10^{2}$ and $0.35 \times 10^{2} \mathrm{CFU} / \mathrm{gm}$ during whole tenure of study. The yeast and mold count was ranged from $0.06 \times 10^{2}$ to $0.12 \times 10^{2} \mathrm{CFU} / \mathrm{gm}$. Simultaneously LDPE packed noodles showed TPC from $0.1 \times 10^{2}$ to $0.42 \times 10^{2} \mathrm{CFU} / \mathrm{gm}$ and yeast and mold was between $0.06 \times 10^{2}$ and $0.26 \times 10^{2} \mathrm{CFU} / \mathrm{gm}$ while study. The comprehensive study of shelf life demonstrates that HDPE packed noodles have better shelf life than LDPE packed noodles as it having less microbial growth.
\end{abstract}

Keywords: Noodles; DSF and DRB; Incorporation; Protein and fiber; Packaging; Shelf life

\section{Introduction}

Noodles are one of the staple foods consumed in many Asian countries. Instant noodles have become internationally recognized food, and worldwide consumption is on the rise. Many researchers are exploring the potential of noodle fortification as an effective public health intervention and improve its nutritional properties. The properties of instant noodles like taste, nutrition, convenience, safety, longer shelf life, and reasonable price have made them popular. Quality factors important for instant noodles are color, flavor, and texture, cooking quality, rehydration rates during final preparation, and the presence or absence of rancid taste after extended storage Gulia et al. [1]. Instant noodles are widely consumed throughout the world and it is a fast-growing sector of the noodle industry. Global consumption of the noodles second only to bread. Noodles are a staple food in many cultures made from unleavened dough which is stretched, extruded, or rolled flat and cut into one of a variety of shapes Okoye et al. [2]. According to Lee et al. [3] noodles came to China as early as $5000 \mathrm{BC}$, and then spread to other Asian countries such as Japan, Thailand, Korea and Malaysia, and now days it has become one of the fastest growing sectors in the world with the compound annual growth rate (CAGR) reaching $4 \%$. Worldwide, China ranks first in the consumption of noodles followed by Indonesia, Japan, and Vietnam according to the world instant noodle association [4] Instant noodles are made from wheat flour, starch, water, salt or kansui (an alkaline salt mixture of sodium carbonate, potassium carbonate, and sodium phosphate), and other ingredients that improve the texture and flavor of noodles, partially cooked by steaming and further cooked and dehydrated by a deep-frying process [5].

Nowadays Consumers all around the world, all are more at the risk of many diseases such as diabetes due to obesity, high cholesterol, cardiovascular diseases, high blood pressure and irregular blood sugar levels. These risk factors are because of the unfit diet which is low in essential nutrients like dietary fiber, phytochemical and antioxidants. Functional foods provide health benefits and help in the avoidance of diseases by incorporating nutraceutical ingredients and other essential nutrients. In the world now days the market of instant noodles gaining popularity. Usually, wheat flour is preferred to prepare instant noodles with low protein and dietary fiber content [6].

Wheat flour noodles can be supplemented with a range of materials that can boost fiber, protein etc. [7]. Recently, food manufacturers have responded to consumer demands for foods with higher fiber content by developing products in which high-fiber ingredients are used dietary fiber can also impart some functional properties to foods, e.g. increase water holding capacity, oil holding capacity, emulsification and/or gel formation. Traditionally, consumers have chosen foods such as whole grains, fruits and vegetables as sources of dietary fiber. Flour of hard wheat (Triticumaestivum $L$.) is the main primary ingredient which is usually used to make instant noodles is low in fiber and protein contents but also poor in essential amino acid, lysine [8]. Noodles also can be made from other flours like rice, buckwheat, and starches derived from potato, sweet potato, and pulses [9]. Most of the essential nutrients are lack in traditional noodles such as dietary fiber, vitamins and minerals, which are lost during wheat flour refinement. Thus, noodle products which represent a major end-use of wheat, are suitable for enhancing health after incorporating sources of fiber and essential nutrients. The essential amino acids are not present in Instant noodles mainly consist of wheat flour whose protein quality is not sufficient [10].

*Corresponding author: Dagadkhair AC, Department of Technology, Food Technology Division, Shivaji University, Kolhapur, MH, India, Tel: 0231-202-0022; E-mail: amoldagadkhair007@gmail.com

Received September 28, 2016; Accepted October 17, 2016; Published October 24, 2016

Citation: Pakhare KN, Dagadkhair AC, Udachan IS, Andhale RA (2016) Studies on Preparation and Quality of Nutritious Noodles by Incorporation of Defatted Rice Bran and Soy Flour. J Food Process Technol 7: 629. doi: 10.4172/2157. 7110.1000629

Copyright: (c) 2016 Pakhare KN, et al. This is an open-access article distributed under the terms of the Creative Commons Attribution License, which permits unrestricted use, distribution, and reproduction in any medium, provided the original author and source are credited. 
The soybean, a grain legume, is one of the richest and cheapest sources of plant protein that can be used to improve the diet of millions of people, especially the poor and low income earners in developing countries. The main ingredients of noodles are wheat, which is having deficiency of essential amino acid lysine, whereas soybean is richer in lysine and can be complement to wheat in noodles. Soybean protein is more economical than high priced meat protein and so they are considered as best source of protein especially in vegetarian diet. It increases nutritional status of vulnerable groups like pregnant woman, nursing mother, school going and young children. High protein soya product reduces incidence of malnutrition and encourage the farmers to grow more soybeans due to increasing demand in the market [11].

Rice bran is a byproduct of rice milling industry and constitutes around $10 \%$ of the total weight of rough rice. It is primarily composed of aleurone, pericarp, sub aleurone layer and germ. Rice bran is a rich source of vitamins, minerals, essential fatty acids, dietary fiber and other sterols. There is a widespread scientific agreement on various health benefits associated with consumption of dietary fiber. Consumer attitude towards health foods is promising and the scope of functional foods is growing in the world markets. Rice bran is finding increased applications in food, nutraceutical and pharmaceutical industries. However, potential applications of rice bran in food industry are limited by its instability owing to rancidity caused by exposure of oil to lipases during milling [12].

Though, the study was carried to produce a fiber and protein rich noodles by incorporating defatted soy flour and defatted rice bran in noodles with its quality analysis and shelf life study in various packaging materials.

\section{Materials and Methods}

\section{Preparation of defatted soy flour (DSF) and defatted rice bran (DRB) incorporated noodles}

The DSF and DRB incorporated noodles were prepared by using standard formulation, which was finalized by comprehensive process of individual sensory evaluation of DSF and DRB incorporated noodles by semi trained panels. The individual DSF incorporated noodles were prepared by addition of $5,10,15$, and 20 percent of DSF in comparison with refined wheat flour. Simultaneously, the DRB incorporated noodles were prepared by taking various trials of DRB incorporation in $2,4,6,8,10,12$, and 15 percent in comparison with refined wheat flour. The comprehensive process of sensory evaluation of incorporated noodles was leads to standardize recipe such as; refined wheat flour 84 g, DSF 10 g, DRB 6 g, water 40 ml, oil 5 g, salt 2 g, Kansui solution 1 g, gluten $2 \mathrm{~g}$ and guar gum $0.2 \mathrm{~g}$. (Figure 1) [13].

\section{Chemical analysis of noodles samples}

The chemical analysis of control noodle sample and noodles incorporated with DSF and DRB were analyzed for moisture, crude protein, crude fat, crude fiber, total ash and calcium by the methods demonstrated by Ranganna [14].

Cooking quality evaluation of noodles: The cooking qualities of the dried noodles were evaluated with respect to cooking time, cooking loss and water uptake Gatade and Sahoo [15].

Cooking time: Optimal cooking time was evaluated by observing the time of disappearance of the core of the noodle strand during cooking (every $20 \mathrm{sec}$ ) by squeezing the noodles between two transparent glass slides.
Cooking loss: The cooking loss was determined by measuring the amount of solid substance lost to cooking water. $10 \mathrm{gm}$ sample of noodles was placed into $100 \mathrm{ml}$ of boiling water in a $500 \mathrm{ml}$ beaker. Cooking water was collected in a pre-weighed glass dish and was placed in a hot air oven at $105^{\circ} \mathrm{C}$ and evaporated to dryness. The dry residue was weighed and reported as a percentage.

Water uptake: The water uptake was calculated by getting the difference between weight of cooked noodles and weight of dried noodles. The cooked noodles were placed on filter paper for $5 \mathrm{~min}$ before weighing, to blot the excess adhered water.

\section{Sensory evaluation}

The sensory evaluation of DSF and DRB incorporated noodles was undertaken by semi trained panel members of department of food technology, department of technology, Shivaji University, Kolhapur. The sensory attributes like appearance, color, taste, flavor, texture and overall acceptability were evaluated by semi trained judges using 9 point hedonic score system. The panelist gives score 9-1 to the product, ranging from 'like extremely' to 'disliked extremely' to find out the most suitable composition of noodles [16].

\section{Effect of storage (Ambient temperature) and packaging material on shelf life of incorporated noodles}

Shelf life study was carried out to determine the keeping quality of product. The effect of packaging material and storage condition on microbial study was determined. The shelf life of any food product is depending on various factors like processing, method of preservation, packaging and microbial count so it founds obligatory to go for microbial examination.

\section{Packaging material used for incorporated noodles}

The high-density polyethylene and low density polyethylene were used for packaging of incorporated noodles.

\section{Selection of raw material}

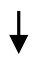

Mixing of ingredients

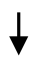

Dough resting for $40 \mathrm{~min}$

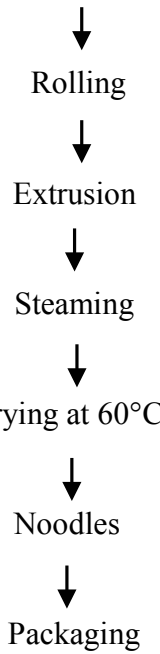

Figure 1: Flow chart for preparation of incorporated noodles. 
Microbial study of incorporated noodles: Microbial study of incorporated noodles was carried by determining Total Plate Count and Yeast Mold count. The methods used for determination of TPC and yeast and mold are explained below.

Total plate count (TPC): The total plate count of incorporated noodles was determined by using simply a total plate count agar (Nutrient agar) method. The pour plate technique was used for the Isolation of microorganisms from the incorporated noodles. The dilutions were made up to $10^{-2}$ by using $1 \mathrm{~g}$ of sample and $0.1 \mathrm{ml}$ of aliquot was used for the isolation. All process was carried out in a strictly sterile area with the help of laminar air flow. Plates were incubated at $37^{\circ} \mathrm{C}$ for $48 \mathrm{hrs}$, and results noted in $\mathrm{cfu} / \mathrm{ml}$.

Total plate count (TPC) of incorporated noodles was examined and the effect of storage and packaging material on microbial quality (TPC) of incorporated noodles was examined on fresh, 15, 30, 45, 60, 75 and 90 days.

Yeast and mold: The yeast and mold count of incorporated noodles was determined by using potato dextrose agar (PDA), the streak plate and pour plate technique were used for the Isolation. The media was sterilized and poured into plates. The dilutions of sample were made up to $10^{-2}$ as like TPC and then $0.1 \mathrm{ml}$ of aliquot was used for streaking. Plates were incubated at $37^{\circ} \mathrm{C}$ for $48-72 \mathrm{hrs}$. and results noted in $\mathrm{cfu} / \mathrm{ml}$.

The yeast and mold count of incorporated noodles was examined and the effect of on storage and packaging material microbial quality (Yeast and Mold) of fish sauce was examined on fresh, 15, 30, 45, 60, 75 and 90 days.

\section{Result and Discussion}

\section{Chemical composition and cooking quality of incorporated noodles with DSF and DRB}

Proximate analysis and cooking quality of incorporated noodles has been studied and presented in below Table 1. The following parameters were checked like moisture, carbohydrate, protein, crude fat, crude fiber, ash and calcium content. In cooking quality evaluation cooking time, cooking loss and water uptake was studied.

The information regarding chemical composition of incorporated noodles emerges from the Table 1 and results found that moisture content was $7.43 \%$, total carbohydrate $68.30 \%$, protein $14.29 \%$, crude fat $4.98 \%$, crude fiber $4.02 \%$, ash $1.54 \%$ and calcium was 498 mg. It could be visualized from the give result that noodles found rich source of carbohydrate and protein along with dietary fiber. As

\begin{tabular}{|c|c|}
\hline Parameters & Value \\
\hline Moisture (\%) & 7.43 \\
\hline Total carbohydrate (\%) & 68.30 \\
\hline Protein (\%) & 14.29 \\
\hline Crude fat (\%) & 4.98 \\
\hline Crude fiber (\%) & 4.02 \\
\hline Ash (\%) & 1.54 \\
\hline Calcium (mg) & 498 \\
\hline Cooking Time (min) & 7.30 \\
\hline Cooking Loss (g) & 1.19 \\
\hline Water Uptake (g) & 10.2 \\
\hline *each result is of three determinations & \\
\hline
\end{tabular}

Table 1: Chemical composition and cooking quality of noodles incorporated noodles with DSF and DRB. incorporated noodles are rich source of dietary fibers it encompasses various health benefits. The protein rich noodles could be prepared by incorporation of defatted soy flour Shogren et al. [17] and Amudha et al. [18]. Cooking time of incorporated noodles was $7.30 \mathrm{~min}$ which was slightly higher than control sample $(7 \mathrm{~min})$. The cooking loss was 1.25 $\mathrm{g}$ which was also quite more than control sample $(1.2 \mathrm{~g})$. Water uptake was also determined and founds $10.5 \mathrm{~g}$ which was also higher than control sample $(10.2 \mathrm{~g})$. The reason behind increase in this cooking quality parameter may be due to increase in protein concentration of incorporated noodles, which directly effects on textural and ultimately cooking quality of noodles.

\section{Effect of storage (Ambient temperature) and packaging material on shelf life of incorporated noodles}

The study was conducted to determine the microbial growth and chemical composition of incorporated noodles in different packaging materials such as high density polyethylene (HDPE) and low density polyethylene (LDPE). As microbial evaluation founds prime factor to determine the shelf life of any food products so, the major emphasis was on microbial study of incorporated noodles. The microbial growth was measured at 15 days' interval up to 90 days; simultaneously the chemical composition of noodles was also analyzed and results are narrated in Table 2. The microbial study was conducted by undertaking total plate count (TPC) and yeast and mold count of incorporated noodles.

The microbial study was conducted by undertaking TPC and yeast and mold count of incorporated noodles. Results were narrated in Tables 2 and 3 .

The TPC of incorporated noodles in HDPE was found within 0.1 $\times 10^{2}$ to $0.35 \times 10^{2}$. From the data in Table 2, it expresses that TPC of fresh sample was $0.1 \times 10^{2}$ which was gradually increased from 15 days $\left(0.22 \times 10^{2}\right)$ to 30 days $\left(0.25 \times 10^{2}\right), 45$ days $\left(0.30 \times 10^{2}\right), 60$ days $\left(0.31 \times 10^{2}\right), 75$ days $\left(0.33 \times 10^{2}\right)$ and $\left(0.35 \times 10^{2}\right)$ at 90 days of study. The Yeast and Mold count was also increased gradually and founds a dominant microflora in incorporated noodles. The yeast and mold count of incorporated noodles was ranged from $0.06 \times 10^{2}$ to $0.12 \times 10^{2}$. On the first day, it was $0.06 \times 10^{2}$ while it was steadily increased from 15 days $\left(0.08 \times 10^{2}\right)$ to 30 days $\left(0.09 \times 10^{2}\right)$, 45 days $\left(0.1 \times 10^{2}\right), 60$ days $\left(0.12 \times 10^{2}\right), 75$ days $\left(0.12 \times 10^{2}\right)$ and $\left(0.13 \times 10^{2}\right)$ at 90 days of study. The similar results regarding microbial characteristics of noodles were discussed by Akhigbemidu et al. [18]

The consistent increased growth in microbes especially Yeast and Mold in incorporated noodles shows that noodles was containing enough moisture and other nutrients required for microbial growth. The reason behind growth of Yeast and Mold could be the lower water activity of incorporated noodles. The TPC of incorporated noodles in LDPE was ranged from $0.1 \times 10^{2}$ to $0.42 \times 10^{2}$. From the Table 3 founds that the fresh sample TPC was $0.1 \times 10^{2}$ which was exponentially increased from 15 days $\left(0.23 \times 10^{2}\right)$ to 30 days $\left(0.25 \times 10^{2}\right)$, 45 days $(0.31$ $\left.\times 10^{2}\right)$, 60 days $\left(0.34 \times 10^{2}\right)$, 75 days $\left(0.38 \times 10^{2}\right)$ and $\left(0.42 \times 10^{2}\right)$ at 90 days of study. Simultaneously LDPE packed incorporated noodles were evaluated for yeast and mold. The given data utters that yeast and mold count of incorporated noodles was ranged from $0.06 \times 10^{2}$ to $0.26 \times 10^{2}$. On the first day, it was $0.06 \times 10^{2}$ while it was gradually increased from 15 days $\left(0.11 \times 10^{2}\right)$ to 30 days $\left(0.15 \times 10^{2}\right), 45$ days $\left(0.18 \times 10^{2}\right), 60$ days $\left(0.19 \times 10^{2}\right), 75$ days $\left(0.21 \times 10^{2}\right)$ and $\left(0.26 \times 10^{2}\right)$ at 90 days of study. The similar results were discussed by [18] ref.

From discussion of Tables 2 and 3 it could be realized that the microbial growth of HDPE packed incorporated noodles was less 
Citation: Pakhare KN, Dagadkhair AC, Udachan IS, Andhale RA (2016) Studies on Preparation and Quality of Nutritious Noodles by Incorporation of Defatted Rice Bran and Soy Flour. J Food Process Technol 7: 629. doi: 10.4172/2157-7110.1000629

Page 4 of 4

\begin{tabular}{|c|c|c|c|c|c|c|c|c|}
\hline \multirow{2}{*}{ Sr. No. } & $\begin{array}{c}\text { Microbial study } \\
\text { parameter }\end{array}$ & \multicolumn{4}{|c|}{ Colony count cfu/gm } \\
\cline { 3 - 8 } & Fresh & $\mathbf{1 5}$ days & $\mathbf{3 0}$ days & $\mathbf{4 5}$ days & $\mathbf{6 0}$ days & $\mathbf{7 5}$ days & $\mathbf{9 0}$ days \\
\hline $\mathbf{1}$ & TPC & $0.1 \times 10^{2}$ & $0.22 \times 10^{2}$ & $0.25 \times 10^{2}$ & $0.30 \times 10^{2}$ & $0.31 \times 10^{2}$ & $0.33 \times 10^{2}$ & $0.35 \times 10^{2}$ \\
\hline $\mathbf{2}$ & Yeast and mold & $0.06 \times 10^{2}$ & $0.08 \times 10^{2}$ & $0.09 \times 10^{2}$ & $0.1 \times 10^{2}$ & $0.12 \times 10^{2}$ & $0.12 \times 10^{2}$ & $0.13 \times 10^{2}$ \\
\hline
\end{tabular}

Table 2: Microbial study of incorporated noodles packed in high density polyethylene (HDPE).

\begin{tabular}{|c|c|c|c|c|c|c|c|c|}
\hline \multirow{2}{*}{ Sr. No. } & $\begin{array}{c}\text { Microbial study } \\
\text { parameter }\end{array}$ & Fresh & $\mathbf{1 5}$ days & $\mathbf{3 0}$ days & $\mathbf{4 5}$ days & $\mathbf{6 0}$ days & $\mathbf{7 5}$ days & $\mathbf{9 0}$ days \\
\cline { 3 - 8 } & TPC & $0.1 \times 10^{2}$ & $0.23 \times 10^{2}$ & $0.25 \times 10^{2}$ & $0.31 \times 10^{2}$ & $0.34 \times 10^{2}$ & $0.38 \times 10^{2}$ & $0.42 \times 10^{2}$ \\
\hline $\mathbf{1}$ & Yeast and mold & $0.06 \times 10^{2}$ & $0.11 \times 10^{2}$ & $0.15 \times 10^{2}$ & $0.18 \times 10^{2}$ & $0.19 \times 10^{2}$ & $0.21 \times 10^{2}$ & $0.26 \times 10^{2}$ \\
\hline
\end{tabular}

Table 3: Microbial study of incorporated noodles packed in low density polyethylene (LDPE).

than LDPE packed noodles. It could be the result of good packaging functionalities of HDPE as compare to LDPE.

\section{Conclusion}

A nutritious noodle could be prepared by incorporation of DSF and DRB in such a way that, it could increase the protein and fiber content up to required optimum level. Soy founds rich source of protein and rice bran founds rich source of fibers, so it could be incorporated in noodles. The noodles packed and stored in HDPE having better storability than LDPE without affecting much quality.

\section{Acknowledgment}

At the outset, I am glad to say thank you to an enthusiastic person Dr. Sahoo A. Director Department of Technology, Shivaji University, Kolhapur for his kind support and guidance. Also, cordially thanks to my research guide Prof. UdachanIranna for their valuable guidance while study.

\section{References}

1. Gulia N, Dhaka V, Khatkar BS (2014) Instant noodles: Processing, quality and nutritional aspects. Food Sci Nutri 54: 1386-1399.

2. Okoye JI, Nkwocha AC, Ogbonnaya AE (2008) Production, proximate composition and consumer acceptability of biscuits from wheat/soybean flour blends. Continent J Food Sci Technol 2: 6-13.

3. Lee SJ, Kim JJ, Moon HI, Ahn JK, Chun SC, et al. (2008) Analysis of isoflavones and phenolic compounds in Korean soybean [Glycine max (L.) Merrill] seeds of different seed weights. J Agri Food Chem 56: 2751-2758.

4. Anonymous (2011) WINA (World instant noodle association): Expanding market.

5. Kim SG (1996) Instant noodles, pasta and noodle technology. American Association of Cereal Chemistry, St Paul MN.
6. Yadav S, Gupta RK (2015) Formulation of noodles using apple pomace and evaluation of its phytochemicals and antioxidant activity. J Pharmacog Phytochem 4: 99-106.

7. Ross AS (2013) Fiber enriched and whole wheat noodles. Food Sci Technol Nutri 3: 291-360.

8. Fu BX (2008) Asian noodles History classification raw materials and processing Food Res Int 41: 888-902.

9. Tan HZ, Li ZG, Tan B (2009) Starch noodles history classification materials processing structure nutrition quality evaluating and improving. Food Res Int 42: 551-576.

10. Neha M, Ramesh C (2014) Development of functional biscuit from soy flour \& rice bran. Int J Agri Food Sci 1: 27-32.

11. Khalid B, Vidhu A, Lubna M (2012) Physio-chemical and sensory characteristics of pasta fortified with chickpea flour and defatted soy flour. J Environment Sci Toxicol Food Technol 1: 34-39.

12. Omeire GC, Umeji OF, Obasi NE (2014) Acceptability of noodles produced from blends of wheat acha and soybean composite flours. Nigeria Food J 32:31-37.

13. Ranganna S (1986) Handbook of analysis and quality control for fruit and vegetable products ( $2^{\text {nd }}$ edn). Tata McGraw Hill Publ Co Ltd, New Delhi.

14. Gatade AA, Sahoo AK (2015) Effect of additives and steaming on quality of air dried noodles. J Food Sci Technol 13: 197-215.

15. Taneya MLJ, Biswas MMH, Shams-Ud-Din M (2014) The studies on the preparation of instant noodles from wheat flour. J Bangladesh Agril Univ 12 : 135-142.

16. Shogren RL, Hareland GA, Wu YV (2006) Sensory evaluation and composition of spaghetti fortified with soy flour. J Food Sci 71: 1750-3841.

17. Amudha S, Ravi R, Bhat KK, Seethalakshmi RM (2002) Studies on the quality of fried snacks based on blends of wheat flour and soya flour. Elsevier Sci.

18. Akhigbemidu W, Musa A, Kuforiji O (2015) Assessment of the microbial qualities of noodles and the accompanying seasonings. Nigeria Food J 33: 48-53. 